Bernd Redecker - Peter Finck - Werner Härdtle Uwe Riecken · Eckhard Schröder (Eds.)

\title{
Pasture Landscapes and Nature Conservation
}

With 167 Figures 


\section{Contents}

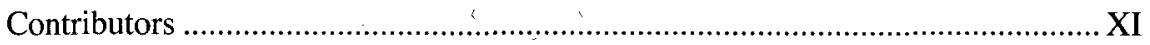

\section{Introduction}

P FINCK, U RIECKEN, E SCHRÖDER

Pasture Landscapes and Nature Conservation - New strategies for preservation of open landscapes in Europe.

H KAMPF

Nature conservation in pastoral-landscapes: Challenges, chances and constraints

\section{Grazing as a phenomenon in Europe}

\section{L-M DELESCAILLE}

Nature conservation and pastoralism in Wallony

P BRANDMAYR, T MingOzZI, S SCALERCIO, N PASSALACQUa, F ROTONDARO, R PIZZOLOTTO

Stipa ausistroitalica garigues and mountain pastureland in the Pollino National Park (Calabria, Southern Italy)

M MAYOR LÓPEZ

Landscapes of northern Spain and pastoral systems

A Didebulidze, H Plachter

Nature conservation aspects of pastoral farming in Georgia.

J TSARYK, I TSARYK

Grazing systems and their influence on biodiversity in the region of the

Dnister river

J SPENCER

Managing wood pasture landscapes in England; the New Forest and other more recent examples

T GREEN

The role of invisible biodiversity in pasture landscapes

\section{Grazing as a Nature Conservation strategy}

W HÄRDTLE, U MiERWALD, T BEHRENDS, I EISCHEID, A GARNIEL, H GRELl, D HAESE, A SCHNEIDER-FENSKE, N VOIGT

Pasture landscapes in Germany - progress towards sustainable use of agricultural land 
A VOIGT

Maintaining biodiversity and open landscapes by grazing in the County of South Jutland, Denmark

P MEIRE, E VAN DEN BERGH, T YsebaeRT, D NiJSSEN

Nature development along the river Scheldt: Combining ecosystem functions in the Kruibeke-Bazel-Rumpelmonde polder....

M LEJEUnE, H LiMPENS, J VAN DER VEEN

The Border Meuse Nature Development Project.

V SLAUKSTINS

The Lake Pape: Grazing of coastal grasslands. WWF Latvia project

G KÄMMER

Galloway-based grazing systems in Schleswig-Holstein (Germany) - projects run by BUNDE WISCHEN e. V. association.

B BEINLICH, P POSCHLOD

Low intensity pig pastures as an alternative approach for habitat management . 219

J SCHRAUTZER, K JeNSEN, B Holsten, U IRMLER, J KiECKBUSCH, U LEINER, C NOELl, R NÖTZOLD, H RECK, B, SCHUlZ, H RowECK

The Eidertal pasture landscape - Mire restoration and species conservation in a river valley of Schleswig-Holstein (northwest Germany)

A Schwabe, D Remy, T Assmann, A Kratochwil, A MÄhrlein, M Nobis, C STORM, A ZEHM, H SCHLEMMER, R SEUSS, S BERGMANN, C Eichberg, U Menzel, M Persigehl, K ZimmermanN, M Weinert Inland Sand Ecosystems: Dynamics and restitution as a consequence of the use of different grazing systems

S BONN

Management concepts for abondoned xerothermic slopes in the middle Rhine Valley: A case study in the sustairiable development of cultural landscapes

\section{J BUTLER}

Examples of the maintenance and restoration of wood pasture sites in the UK and the potential for creation

F J Silva-PANdo, M J Rozados LoREnZo, M P GonzÁlez HERnÁNDEZ Grasslands and scrublands in the northwest of the Iberian Peninsula:

Silvopastoral systemy and nature conservation

B GERKEN, H SONNENBURG

Landscape development and species protection in woodlands, forests and pastures using large herbivores.

\section{F BAERSELMAN}

The Large Herbivore Initiative: An Eurasian conservation and restoration programme for a key-species group in ecosystems (Europe, Russia, CentralAsia and Mongolia). 
H LIMPENS, M LEJEUNE, J VAN DER VEEN

Urbanized man and the longing for a New Wilderness

R LUICK, E BIGNAL

The significance of EU agricultural policy on the nature conservation of pastoral farmland

\section{Grazing and habitat dynamics - results of scientific research}

M CONRADI

Methods for the investigation of patterns and processes in large-scale grazing systems

A BONTJER, H PLACHTER

Effects of large-scale cattle grazing on Orthoptrea (Saltatoria et Mantodea)

on pastures in Georgia (Caucasus)

P Poschlod, M SchNeIDER-JACOBY, H KÖSTERMEYER, B T HILL,

B BEINLICH

Does large-scale, multi-species pasturing maintain high biodiversity with rare and endangered species? - The Sava floodplain case study

R SATZGER :

Large-scale grazing systems by herdsmen and their impact on landscape patterns and biodiversity in western Ukraine's Carpathians

D Scholle, C Hofmann, G Kaule, D Lederbogen, G Rosenthal, U THUMM, J TRAAUTNER

Co-operative grazing systems ("Allmende"): An alternative concept for the management of endangered open and semi-open landscapes.

M Kleyer, R Biedermann, K Henle, H J Poethke, P Poschlod, J SETTELE

MOSAIK: Semi-open pasture and ley - a research project on keeping the culural landscape open

W Völkl, A Von Heßberg, D Mader, J Metzner, P Gerstberger, K H HOFFMENN, H REBHAN, R KREC

Natural succession in a dynamic riverine landscape and the protection of open areas.

\section{Outlook}

U RIECKEN, P FINCK, E SCHRÖDER

Significance of pasture landscapes for nature conservation and extensive agriculture 